\title{
Influence of Deficit Irrigation Using Different Irrigation Methods and Fertilizer Levels on Performance of Turmeric
}

\begin{tabular}{|c|c|}
\hline \multicolumn{2}{|r|}{$\begin{array}{c}\text { Department of Agronomy, University of Agricultural Sciences, } \\
\text { Dharwad- 580005, Karnataka, India } \\
* \text { Corresponding author }\end{array}$} \\
\hline \multicolumn{2}{|r|}{ A B S T R A C T } \\
\hline & \multirow{6}{*}{$\begin{array}{l}\text { A field experiment was conducted to study the influence of deficit irrigation using } \\
\text { different irrigation methods and fertilizer levels on performance of turmeric varieties a } \\
\text { University of Agricultural Sciences, Dharwad. The experiment was laid out in split- spli } \\
\text { plot design, keeping irrigation methods (Drip, sprinkler and ridges and furrow irrigation } \\
\text { applied as deficit irrigation at } 50 \% \text { depletion of soil moisture) in main plot; varieties (cv } \\
\text { Cudappah and cv. Pratibha) in sub plot and fertilizer levels (180:90:90, 225:112.5:135 and } \\
270: 135: 180 \mathrm{~kg} \mathrm{~N}: \mathrm{P}_{2} \mathrm{O}_{5}: \mathrm{K}_{2} \mathrm{O} \text { ha } \mathrm{a}^{-1} \text { ) in sub-sub plot. Higher growth observed in terms of lea } \\
\text { area, chlorophyll content at } 150 \mathrm{DAP} \text { and total dry matter production at harvest were } \\
\text { recorded with drip irrigation. Significantly higher total fresh rhizome, fresh mother } \\
\text { rhizomes and cured finger rhizome yield were observed in drip irrigation method applied } \\
\text { at } 50 \text { per cent depletion of soil moisture. Superiority of performance of cv. Cudappah } \\
\text { variety was observed over cv. Pratibha in terms of leaf area, chlorophyll content TDM and } \\
\text { yield. Application of } 270: 135: 180 \mathrm{~kg} \mathrm{~N}: \mathrm{P}_{2} \mathrm{O}_{5}: \mathrm{K}_{2} \mathrm{O} \text { ha }{ }^{-1} \text { resulted in higher fresh rhizomes } \\
\text { mother rhizomes and cured finger rhizome yield which was on par with application of } \\
225: 112.5: 135 \mathrm{~kg} \mathrm{~N}: \mathrm{P}_{2} \mathrm{O}_{5}: \mathrm{K}_{2} \mathrm{O} \text { ha }{ }^{-1} \text {. Interaction influence of the irrigation methods } \\
\text { varieties and fertilizer indicated higher growth and yield in treatment applied with } \\
\text { irrigation at } 50 \text { per cent soil moisture depletion through drip irrigation with cv. Cudappah } \\
\text { and application of } 270: 135: 180 \mathrm{~kg} \mathrm{~N}: \mathrm{P}_{2} \mathrm{O}_{5}: \mathrm{K}_{2} \mathrm{O} \text { ha }{ }^{-1} \text { which was statistically on par with } \\
\mathrm{I}_{1} \mathrm{~V}_{1} \mathrm{~F}_{2} \text { and } \mathrm{I}_{1} \mathrm{~V}_{2} \mathrm{~F}_{3} \text {. }\end{array}$} \\
\hline Keywords & \\
\hline $\begin{array}{l}\text { eficit irrigation, } \\
\text { rigation methods, } \\
\text { ertilizer levels, } \\
\text { urmeric yield and } \\
\text { otal dry matter } \\
\text { roduction. }\end{array}$ & \\
\hline Article Info & \\
\hline $\begin{array}{l}\text { Accepted: } \\
12 \text { September } 2017 \\
\text { Available Online: } \\
10 \text { November } 2017\end{array}$ & \\
\hline & \\
\hline
\end{tabular}

\section{Introduction}

Turmeric is one of the important spices grown for domestic consumption and export owing to its wide range of fields of utilities covering culinary to medicine. Globally, India occupies the first position in the world (Siddramappa, 2013) with an area of 1.90 lakh hectares and also produces 8.44 lakh tonnes (Anon., 2017). It is well understood that, moisture during the different growth stages play a major role in expressing full potentiality of crop. However, farmers often over irrigate through increased irrigation frequency and amount of water applied causing deleterious effect on the applied nutrients, water and soil properties. Climate change and prevailing seasonal water deficit endeavours for improvement the agronomic practices for addressing the water deficit situation.

Deficit irrigation is one such approach to reduce the water consumption. In general different irrigation methods induce differential effect on the crop response and more so under deficit irrigation. Further, there 
is always a need to maximize water use efficiency without scarifying production because of variation in rainfall characteristics, increasing competition for water, with increase in energy costs and competing demand in all the sectors. This can be achieved by use of improved pressurized irrigation methods over conventional irrigation practices (Chitra et al., 2017).

Further balanced nutrition is essential part of the crop husbandry practice to moderate the prevailing soil water regime. Differential response of the genotypes exists due to their genetic makeup which needs to be exploited (Sandeep et al., 2016). Influence on the interaction effect of different irrigation methods under deficit irrigation with varied nutrient levels and genotype is meagre. Hence, an experiment was conducted to study the "Influence of deficit irrigation using different irrigation methods and fertilizer levels on performance of turmeric".

\section{Materials and Methods}

Experimental site was located at the Agricultural Research Station (ARS), Kalloli, University of Agricultural Sciences, Dharwad during 2013-14. Soil type observed in the experimental site was medium deep black clayey soil with alkaline in $\mathrm{pH}(8.3)$, low in available nitrogen $\left(243 \mathrm{~kg} \mathrm{ha}^{-1}\right)$, medium in available phosphorus ( $\left.32 \mathrm{~kg} \mathrm{ha}^{-1}\right)$ and high in available potassium $\left(318 \mathrm{~kg} \mathrm{ha}^{-1}\right)$. Experiment was laid in split split plot design with three replications. Treatments were assigned as below:

\section{Main plot: Deficit irrigation at $50 \%$ soil moisture depletion using different irrigation methods}

$\mathrm{I}_{1}$ : Drip irrigation

$\mathrm{I}_{2}$ : Ridges and furrow irrigation

$\mathrm{I}_{3}$ : Sprinkler irrigation
Sub-plot: Varieties (V)

$\mathrm{V}_{1}$ : Cudappah

$\mathrm{V}_{2}$ : Pratibha

Sub-sub-plot: Fertilizers levels (F) \#

$\mathrm{F}_{1}: 180: 90: 90 \mathrm{~kg} \mathrm{~N}: \mathrm{P}_{2} \mathrm{O}_{5}: \mathrm{K}_{2} \mathrm{O} \mathrm{ha}^{-1}$

$\mathrm{F}_{2}: 225: 112.5: 135 \mathrm{~kg} \mathrm{~N}: \mathrm{P}_{2} \mathrm{O}_{5}: \mathrm{K}_{2} \mathrm{O}$ ha $^{-1}$

$\mathrm{F}_{3}: 270: 135: 180 \mathrm{~kg} \mathrm{~N}: \mathrm{P}_{2} \mathrm{O}_{5}: \mathrm{K}_{2} \mathrm{O}$ ha $^{-1}$

\# Nitrogen and potassium were soil applied in five splits at monthly interval starting from planting. While entire $\mathrm{P}_{2} \mathrm{O}_{5}$ was applied as basal dose at the time of planting. Fertilizer were applied with Urea, DAP and MOP as source of the nutrients. Drip irrigation was applied with $41 \mathrm{hr}^{-1}$ discharge emitter ${ }^{-1}$ with lateral placed every two rows of the turmeric plants. All standard agronomic practices were followed uniformly across the treatments during the conduct of the experiment. Growth observed during the conduct of the experiment is expressed as leaf area $\left(\mathrm{dm}^{2}\right.$ plant $^{-1}$ ) and chlorophyll content (SPAD values) at 150 DAP (days after planting) and total dry matter production per plant at harvest. Fresh rhizomes were harvested at maturity by digging and removing of the roots. Fresh rhizome yield presented is cumulative of the all the rhizomes harvested (Mother, primary, secondary and tertiary rhizomes). Fresh mother rhizomes were separated from the harvested rhizome and yield of the mother rhizomes were recorded separately as these were not subjected to curing process. Whereas, primary, secondary and tertiary rhizomes were subjected to curing process and the end product is presented as cured finger rhizome yield. The data collected from the experiment was subjected to statistical analysis and interpretation of data was done using the Fischer's method of analysis of variance technique as described by Gomez and Gomez (1984). The level of significance used in ' $\mathrm{F}$ ' and ' $\mathrm{t}$ ' test was $\mathrm{P}=$ 
0.05. The mean values for main plot, sub plot, sub sub plot and interactions were separately subjected to Ducan multiple range test (DMRT) using corresponding error mean sum of square and degrees of freedom.

\section{Results and Discussion}

Deficit irrigation through different irrigation methods induced differential response in fresh rhizome yield and the fresh mother rhizome yield (Table 3). Drip irrigation applied at 50 per cent available soil moisture depletion recorded higher yield response in comparison to other irrigation methods evaluated. Drip irrigation at 50 per cent soil moisture depletion resulted in better water regime with retention of moisture within the active root zone of turmeric which facilitated for better uptake of the nutrients. Drip irrigation might have resulted in improvement of the biometric parameters resulting in better maintenance of relative water content in leaves. This might have induced progressive effect on growth attributes, extended period of greenness of crop is an indicative of profuse expansion of photosynthetic area and translocation of the absorbed nutrients as indicated by leaf area and chlorophyll content at 150 DAP and TDM at harvest (Table 1). Yield response to drip irrigation at 50 per cent soil moisture depletion was significantly higher over other methods (Table 3). Drip irrigation recorded higher fresh rhizomes (25.85 t/ha), fresh mother rhizomes (5.86 t/ha) and cured finger rhizomes yield per ha (3.97 t/ha). Whereas, corresponding lower yield was recorded with furrow irrigation at 50 per cent soil moisture depletion. Furrow irrigation at 50 per cent soil moisture depletion might have resulted in the loss of added nutrients through leaching, runoff and other factors. On the contrary drip irrigation at 50 per cent soil moisture depletion might had facilitated for better development of rhizomes directly infusing higher nutrients into the rhizome resulting in increment of both rhizome volume and weight in comparison to other irrigation methods evaluated. Presented results are in corroboration with the findings of Kaur and Brar (2016); Surepaddi et al., (2016). Comparison among the varieties evaluated indicated progressive growth in cv. Cudappah induced higher translocation of the absorbed nutrients resulted in higher yield. Relatively higher absorption of soil moisture and nutrients on account of profused improvement in growth attributes as indicated by the higher leaf area and chlorophyll at peak growth stage and TDM at harvest might have contributed to increase in yield attributes of turmeric. Higher fresh rhizomes (24.33 t/ha); mother rhizomes (5.63 t/ha) and cured finger rhizomes yield (3.85 t/ha) were observed in Cudappah. Results are in corroboration with the findings of Salimath et al., (2013). Graded levels of fertilizer levels resulted in significant variation in growth attributes as indicated by higher leaf area, chlorophyll content at peak growth stage (150 DAP) and TDM at harvest.

Application of 270:135:180 kg N: $\mathrm{P}_{2} \mathrm{O}_{5}: \mathrm{K}_{2} \mathrm{O}$ per ha recorded significantly higher values of biometric parameters. Application of nitrogen and potassium in increased split applications resulted in response of the turmeric to higher levels of fertilizer against recommended dose of fertilizer (Jagadeeswaran et al., 2005). Higher doses of nitrogen might have contributed to improvement in synthesis of protein which is important for buildup of new cells and consequently influenced the growth (Salisbury and Ross, 1969). Increased potassium levels increased the potassium content in plants which functionally acts as transporter of photosynthates to the economic parts contributing to increased yield. Additionally increased potassium application address the deficit irrigation situation by way of stomatal regulation improves capacity of the crop to resist drought and alleviate the negative effects on growth and development. 
Table.1 Influence of irrigation methods, varieties and fertilizer levels on leaf area and Chlorophyll content (SPAD value) at 150 DAP and total dry matter production at harvest of turmeric

\begin{tabular}{|c|c|c|c|}
\hline Treatment details & $\begin{array}{c}\text { Leaf area }\left(\mathrm{dm}^{2} \text { plant }^{-1}\right) \\
\text { at } 150 \text { DAP }\end{array}$ & $\begin{array}{c}\text { Chlorophyll content } \\
\text { (SPAD value) at } 150 \\
\text { DAP }\end{array}$ & $\begin{array}{c}\text { Total dry matter } \\
\left.\text { Production (g plant }^{-1}\right) \text { at } \\
\text { harvest }\end{array}$ \\
\hline \multicolumn{4}{|c|}{$\begin{array}{l}\text { Main plot (Irrigation at } 50 \% \text { soil moisture } \\
\text { depletion) }\end{array}$} \\
\hline $\mathrm{I}_{1}$ : Drip irrigation & $50.0 \mathrm{a}$ & $31.2 \mathrm{a}$ & $126.4 \mathrm{a}$ \\
\hline $\mathrm{I}_{2}:$ Ridges and furrow irrigation & $45.6 \mathrm{~b}$ & $28.7 b$ & $109.8 \mathrm{c}$ \\
\hline $\mathrm{I}_{3}:$ Sprinkler irrigation & $47.8 \mathrm{ab}$ & $29.5 b$ & $112.2 b$ \\
\hline S.Em. \pm & 0.8 & 0.3 & 1.4 \\
\hline \multicolumn{4}{|l|}{ Sub plot (Varieties) } \\
\hline $\mathrm{V}_{1}$ : Cudappah & $48.9 \mathrm{a}$ & $30.4 \mathrm{a}$ & $123.2 \mathrm{a}$ \\
\hline $\mathrm{V}_{2}$ : Pratibha & $46.7 b$ & $29.3 b$ & $109.2 b$ \\
\hline S.Em. \pm & 0.5 & 0.3 & 1.6 \\
\hline \multicolumn{4}{|l|}{ Sub Sub plot (Fertilizer levels) } \\
\hline $\mathrm{F}_{1}: 180: 90: 90 \mathrm{~kg} \mathrm{~N}: \mathrm{P}_{2} \mathrm{O}_{5}: \mathrm{K}_{2} \mathrm{O} \mathrm{ha}^{-1}$ & $46.3 \mathrm{c}$ & $29.2 b$ & $110.4 \mathrm{c}$ \\
\hline $\mathrm{F}_{2}: 225: 112.5: 135 \mathrm{~kg} \mathrm{~N}: \mathrm{P}_{2} \mathrm{O}_{5}: \mathrm{K}_{2} \mathrm{O} \mathrm{ha}^{-1}$ & $47.6 \mathrm{~b}$ & $29.9 \mathrm{ab}$ & $116.1 \mathrm{~b}$ \\
\hline $\mathrm{F}_{3}: 270: 135: 180 \mathrm{~kg} \mathrm{~N}: \mathrm{P}_{2} \mathrm{O}_{5}: \mathrm{K}_{2} \mathrm{O} \mathrm{ha}^{-1}$ & $49.6 \mathrm{a}$ & $30.5 \mathrm{a}$ & $121.9 \mathrm{a}$ \\
\hline S.Em. \pm & 0.6 & 0.3 & 0.9 \\
\hline
\end{tabular}

Means followed by the same letter (s) within a column are not significantly differed by DMRT ( $\mathrm{P}=0.05)$ 
Table.2 Interaction effect of irrigation methods, varieties and fertilizer levels on leaf area and Chlorophyll content (SPAD value) at 150 DAP and total dry matter production at harvest of turmeric

\begin{tabular}{|c|c|c|c|}
\hline Interaction Treatment (I x V x F) & $\begin{array}{c}\text { Leaf area }\left(\mathrm{dm}^{2} \text { plant }^{-1}\right) \\
\text { at } 150 \text { DAP }\end{array}$ & $\begin{array}{c}\text { Chlorophyll content } \\
\text { (SPAD value) at } 150 \text { DAP }\end{array}$ & $\begin{array}{c}\text { Total dry matter production } \\
\left(\mathrm{g} \mathrm{plant}^{-1}\right) \text { at harvest }\end{array}$ \\
\hline$I_{1} V_{1} F_{1}$ & $49.7 \mathrm{bc}$ & 31.1a-e & $124.5 \mathrm{~cd}$ \\
\hline$I_{1} V_{1} F_{2}$ & $51.3 \mathrm{ab}$ & $32.0 \mathrm{ab}$ & $131.6 \mathrm{~b}$ \\
\hline$I_{1} V_{1} F_{3}$ & $54.9 a$ & $32.4 a$ & $139.9 \mathrm{a}$ \\
\hline$I_{1} V_{2} F_{1}$ & $47.1 b-d$ & 29.7a-e & $113.8 \mathrm{e}-\mathrm{g}$ \\
\hline$I_{1} V_{2} F_{2}$ & $48.2 \mathrm{bc}$ & $30.7 a-d$ & 119.8de \\
\hline$I_{1} V_{2} F_{3}$ & $48.8 \mathrm{bc}$ & $31.5 \mathrm{a}-\mathrm{c}$ & $128.9 \mathrm{bc}$ \\
\hline$I_{2} V_{1} F_{1}$ & $44.8 \mathrm{~cd}$ & 29.1a-e & $113.9 \mathrm{e}-\mathrm{g}$ \\
\hline$I_{2} V_{1} F_{2}$ & 46.1b-d & $29.4 b-e$ & $119.7 \mathrm{de}$ \\
\hline$I_{2} V_{1} F_{3}$ & $47.9 \mathrm{bc}$ & 29.9a-e & $122.6 \mathrm{~cd}$ \\
\hline$I_{2} V_{2} F_{1}$ & $42.1 \mathrm{~d}$ & $27.9 \mathrm{e}$ & $97.5 \mathrm{i}$ \\
\hline$I_{2} V_{2} F_{2}$ & $45.6 \mathrm{~cd}$ & $28.3 \mathrm{de}$ & $100.4 \mathrm{i}$ \\
\hline$I_{2} V_{2} F_{3}$ & $47.2 \mathrm{~b}-\mathrm{d}$ & $25.9 \mathrm{c}$ & 104.7hi \\
\hline$I_{3} V_{1} F_{1}$ & 46.1b-d & $29.3 c-e$ & $114.6 \mathrm{e}-\mathrm{g}$ \\
\hline$I_{3} V_{1} F_{2}$ & $48.4 \mathrm{bc}$ & $30.0 \mathrm{a}-\mathrm{e}$ & $117.5 \mathrm{~d}-\mathrm{f}$ \\
\hline$I_{3} V_{1} F_{3}$ & $51.0 \mathrm{ab}$ & $30.1 \mathrm{a}-\mathrm{e}$ & $123.9 \mathrm{~cd}$ \\
\hline $\mathbf{I}_{3} \mathbf{V}_{2} \mathbf{F}_{1}$ & $47.8 \mathrm{bc}$ & $27.9 \mathrm{e}$ & $98.1 \mathrm{i}$ \\
\hline$I_{3} V_{2} F_{2}$ & $46.2 b-d$ & $28.9 \mathrm{c}-\mathrm{e}$ & $107.7 \mathrm{gh}$ \\
\hline$I_{3} V_{2} F_{3}$ & $47.6 \mathrm{bc}$ & $31.0 \mathrm{a}-\mathrm{c}$ & $111.4 \mathrm{f}-\mathrm{h}$ \\
\hline S.Em. \pm & 1.5 & 0.8 & 2.3 \\
\hline
\end{tabular}

Means followed by the same letter (s) within a column are not significantly differed by DMRT $(\mathrm{P}=0.05)$

Irrigation methods (I) - at $50 \%$ soil moisture depletion

$\mathrm{I}_{1}$ : Drip irrigation

$\mathrm{I}_{2}$ : Ridges and furrow irrigation

$\mathrm{I}_{3}$ : Sprinkler irrigation
Varieties (V)

$\mathrm{V}_{1}$ : Cudappah

$\mathrm{V}_{2}$ : Pratibha

\section{Fertilizer levels (F)}

$\mathrm{F}_{1}: 180: 90: 90 \mathrm{~kg} \mathrm{~N}: \mathrm{P}_{2} \mathrm{O}_{5}: \mathrm{K}_{2} \mathrm{O} \mathrm{ha}^{-1}$

$\mathrm{F}_{2}: 225: 112.5: 135 \mathrm{~kg} \mathrm{~N}: \mathrm{P}_{2} \mathrm{O}_{5}: \mathrm{K}_{2} \mathrm{O}$ ha ${ }^{-1}$

$\mathrm{F}_{3}: 270: 135: 180 \mathrm{~kg} \mathrm{~N}: \mathrm{P}_{2} \mathrm{O}_{5}: \mathrm{K}_{2} \mathrm{O} \mathrm{ha}^{-1}$ 
Table.3 Influence of irrigation methods, varieties and fertilizer levels on fresh rhizome, fresh mother rhizome and cured finger rhizome yield of turmeric

\begin{tabular}{|c|c|c|c|}
\hline Treatment details & $\begin{array}{l}\text { Fresh rhizome } \\
\text { Yield }\left(\mathrm{t} \mathrm{ha}^{-1}\right)\end{array}$ & $\begin{array}{l}\text { Fresh mother } \\
\left.\text { rhizome yield (t ha }{ }^{-1}\right)\end{array}$ & $\begin{array}{c}\text { Cured finger rhizome } \\
\text { yield }\left(\mathrm{t} \mathrm{ha}^{-1}\right)\end{array}$ \\
\hline \multicolumn{4}{|c|}{ Main plot (Irrigation at $50 \%$ soil moisture depletion) } \\
\hline $\mathrm{I}_{1}$ : Drip irrigation & $25.85 \mathrm{a}$ & $5.86 \mathrm{a}$ & $3.97 \mathrm{a}$ \\
\hline $\mathrm{I}_{2}$ : Ridges and furrow irrigation & $22.42 b$ & $5.25 b$ & $3.37 \mathrm{~b}$ \\
\hline $\mathrm{I}_{3}:$ Sprinkler irrigation & $22.98 b$ & $5.37 \mathrm{~b}$ & $3.46 b$ \\
\hline S.Em. \pm & 0.42 & 0.05 & 0.06 \\
\hline \multicolumn{4}{|l|}{ Sub plot (Varieties) } \\
\hline $\mathrm{V}_{1}$ : Cudappah & $24.33 \mathrm{a}$ & $5.63 \mathrm{a}$ & $3.85 \mathrm{a}$ \\
\hline $\mathrm{V}_{2}$ : Pratibha & $23.16 b$ & $5.35 b$ & $3.35 b$ \\
\hline S.Em. \pm & 0.34 & 0.08 & 0.08 \\
\hline \multicolumn{4}{|l|}{ Sub Sub plot (Fertilizer levels) } \\
\hline $\mathrm{F}_{1}: 180: 90: 90 \mathrm{~kg} \mathrm{~N}: \mathrm{P}_{2} \mathrm{O}_{5}: \mathrm{K}_{2} \mathrm{O} \mathrm{ha}^{-1}$ & $22.07 \mathrm{c}$ & $5.17 \mathrm{~b}$ & $3.39 b$ \\
\hline $\mathrm{F}_{2}: 225: 112.5: 135 \mathrm{~kg} \mathrm{~N}: \mathrm{P}_{2} \mathrm{O}_{5}: \mathrm{K}_{2} \mathrm{O} \mathrm{ha}^{-1}$ & $24.14 b$ & $5.56 \mathrm{a}$ & $3.65 \mathrm{a}$ \\
\hline $\mathrm{F}_{3}: 270: 135: 180 \mathrm{~kg} \mathrm{~N}: \mathrm{P}_{2} \mathrm{O}_{5}: \mathrm{K}_{2} \mathrm{O} \mathrm{ha}^{-1}$ & $25.04 \mathrm{a}$ & $5.74 a$ & $3.76 a$ \\
\hline S.Em. \pm & 0.25 & 0.06 & 0.05 \\
\hline
\end{tabular}

Means followed by the same letter (s) within a column are not significantly differed by DMRT $(\mathrm{P}=0.05)$ 
Table.4 Interaction effect of irrigation methods, varieties and fertilizer levels on fresh rhizome, fresh mother rhizome and cured finger rhizome yield of turmeric

\begin{tabular}{|c|c|c|c|}
\hline 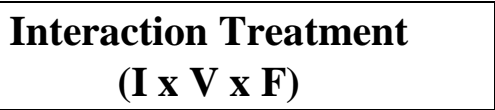 & $\begin{array}{l}\text { Fresh rhizome } \\
\text { yield }\left(\mathrm{t} \mathrm{ha}^{-1}\right)\end{array}$ & $\begin{array}{c}\text { Fresh mother } \\
\text { rhizome yield }\left(\mathrm{t} \mathrm{ha} \mathbf{h}^{-1}\right)\end{array}$ & $\begin{array}{c}\text { Cured finger } \\
\text { rhizome yield }\left(\mathrm{tha}^{-1}\right)\end{array}$ \\
\hline$I_{1} V_{1} F_{1}$ & $24.75 \mathrm{~cd}$ & $5.68 \mathrm{~cd}$ & $4.00 b c$ \\
\hline$I_{1} V_{1} F_{2}$ & $27.13 \mathrm{a}$ & $6.17 \mathrm{ab}$ & $4.26 \mathrm{ab}$ \\
\hline$I_{1} V_{1} F_{3}$ & $28.18 \mathrm{a}$ & $6.38 \mathrm{a}$ & $4.45 \mathrm{a}$ \\
\hline$I_{1} V_{2} F_{1}$ & $23.00 \mathrm{~d}-\mathrm{g}$ & $5.22 \mathrm{de}$ & $3.45 \mathrm{e}-\mathrm{g}$ \\
\hline$I_{1} V_{2} F_{2}$ & $25.18 b c$ & $5.65 \mathrm{~cd}$ & $3.76 \mathrm{f}$ \\
\hline$I_{1} V_{2} F_{3}$ & $26.85 \mathrm{ab}$ & $6.04 a-c$ & $3.91 \mathrm{~b}$ \\
\hline$I_{2} V_{1} F_{1}$ & $21.27 \mathrm{~g}-\mathrm{i}$ & $4.93 \mathrm{e}$ & $3.46 \mathrm{e}-\mathrm{g}$ \\
\hline$I_{2} V_{1} F_{2}$ & $23.25 \mathrm{c}-\mathrm{g}$ & $5.37 \mathrm{de}$ & $3.71 \mathrm{f}$ \\
\hline $\mathbf{I}_{\mathbf{2}} \mathbf{V}_{\mathbf{1}} \mathbf{F}_{3}$ & $24.17 \mathrm{c}-\mathrm{e}$ & $5.53 \mathrm{~d}$ & $3.80 \mathrm{~b}$ \\
\hline$I_{2} V_{2} F_{1}$ & $20.50 \mathrm{i}$ & $4.94 \mathrm{e}$ & $2.89 \mathrm{i}$ \\
\hline $\mathbf{I}_{2} \mathbf{V}_{2} \mathbf{F}_{2}$ & $22.47 \mathrm{e}-\mathrm{i}$ & $5.32 \mathrm{de}$ & $3.15 \mathrm{~g}-\mathrm{i}$ \\
\hline$I_{2} V_{2} F_{3}$ & $22.87 \mathrm{~d}-\mathrm{h}$ & 5.40de & $3.21 \mathrm{c}$ \\
\hline $\mathbf{I}_{3} V_{1} F_{1}$ & $22.00 \mathrm{f}-\mathrm{i}$ & $5.28 \mathrm{de}$ & $3.54 \mathrm{~d}-\mathrm{g}$ \\
\hline$I_{3} V_{1} F_{2}$ & 23.90c-f & $5.60 \mathrm{~cd}$ & $3.70 \mathrm{c}-\mathrm{f}$ \\
\hline$I_{3} V_{1} F_{3}$ & $24.35 \mathrm{c}-\mathrm{e}$ & $5.71 b-d$ & $3.76 \mathrm{~b}$ \\
\hline $\mathbf{I}_{3} \mathbf{V}_{2} \mathbf{F}_{1}$ & 20.90hi & $4.97 \mathrm{e}$ & 3.01hi \\
\hline$I_{3} V_{2} F_{2}$ & 22.92d-h & 5.26de & $3.33 \mathrm{f}-\mathrm{h}$ \\
\hline $\mathbf{I}_{\mathbf{3}} \mathbf{V}_{\mathbf{2}} \mathbf{F}_{\mathbf{3}}$ & $23.80 \mathrm{c}-\mathrm{f}$ & $5.39 \mathrm{de}$ & $3.42 b c$ \\
\hline S.Em. \pm & 0.61 & 0.15 & 0.13 \\
\hline
\end{tabular}

Means followed by the same letter (s) within a column are not significantly differed by DMRT ( $\mathrm{P}=0.05)$

\section{Irrigation methods (I) - at $50 \%$ soil moisture $\quad$ Varieties (V) Fertilizer levels (F)}

depletion
$\mathrm{I}_{1}$ : Drip irrigation

$\mathrm{V}:$ Cudappa

$\mathrm{I}_{1}$ : Drip irrigation
$\mathrm{I}_{2}:$ Ridges and furrow irrigation

$\mathrm{V}_{2}$ : Pratibha

(20.90:90 kg N: $\mathrm{P}_{2} \mathrm{O}_{5}: \mathrm{K}_{2} \mathrm{O}$ ha $^{-1}$

$\mathrm{I}_{3}$ : Sprinkler irrigation

$\mathrm{F}_{2}: 225: 112.5: 135 \mathrm{~kg} \mathrm{~N}: \mathrm{P}_{2} \mathrm{O}_{5}: \mathrm{K}_{2} \mathrm{O}$ ha $^{-1}$

$\mathrm{F}_{3}: 270: 135: 180 \mathrm{~kg} \mathrm{~N}: \mathrm{P}_{2} \mathrm{O}_{5}: \mathrm{K}_{2} \mathrm{O}^{-1} \mathrm{ha}^{-1}$ 
Imperatively increased $\mathrm{K}_{2} \mathrm{O}$ levels increase the yield irrespective of irrigation methods (Ati et al., 2012). Further phosphorus facilitates plant to respond to $\mathrm{N}$ and $\mathrm{K}_{2} \mathrm{O}$ fertilization. Increased response of the applied nitrogen with increase in potassium levels contributing to the improvement in crop growth was observed (Aulakh and Malhi, 2005). Higher fresh rhizomes yield (25.04 $\mathrm{t} / \mathrm{ha})$; fresh mother rhizomes yield $(5.74 \mathrm{t} / \mathrm{ha})$ and cured finger rhizome yield (3.76 t/ha) were observed with application of 270:135:180 kg N: $\mathrm{P}_{2} \mathrm{O}_{5}: \mathrm{K}_{2} \mathrm{O}$ per ha over other fertilizer levels. However it was on par with 225:112.5:135 $\mathrm{kg} \mathrm{N}: \mathrm{P}_{2} \mathrm{O}_{5}: \mathrm{K}_{2} \mathrm{O}$ ha $^{-1}$. Propelled improvement in crop growth and yield was also due synergetic effect of NxPxK interaction in turmeric. Turmeric is high responsive crop to applied potassium which might have reflected to the increased $\mathrm{KN}$ ratio in the applied fertilizer (0.67) as compared to application of 180:90:90 kg N: $\mathrm{P}_{2} \mathrm{O}_{5}: \mathrm{K}_{2} \mathrm{O}$ per ha $(0.50)$. This may be due to higher increased response in terms of the yield attributes.

Response of particular variety to irrigation and fertilizers is a genotypic character. Seyie et al., (2013) and Tiwari et al., (2014) recorded similar observation of differential yield response in genotypes to graded level of fertilizers. $\mathrm{Cv}$. Cudappah responded better in comparison to $\mathrm{cv}$. Pratibha with fertilizer levels and drip irrigation. Drip irrigation at 50 per cent depletion of the soil moisture depletion with fertilizers induced significant variation in the performance of turmeric across both the varieties evaluated. Higher levels of soil applied fertilizers to drip irrigated plot resulted in higher growth and yield attributes in comparison to surface irrigation (Table 2 and 4). Similar results were observed by Sadarunnisa et al., (2010). Irrigation, variety and fertilizer interactions differed significantly with respect to plant growth and yield characteristics as evidenced by the leaf area, chlorophyll content and total dry matter accumulation (Table 2). Drip irrigation at 50 per cent soil moisture depletion with application of 270:135:180 kg $\mathrm{N}$ : $\mathrm{P}_{2} \mathrm{O}_{5}: \mathrm{K}_{2} \mathrm{O}$ per ha in cv. Cudappah $\left(\mathrm{I}_{1} \mathrm{~V}_{1} \mathrm{~F}_{3}\right)$ higher growth fresh rhizome (28.18 t/ha), fresh mother rhizome yield (6.38 t/ha) and cured finger rhizome yield (4.45 t/ha). It was on par with drip irrigation at 50 per cent soil moisture depletion with application of 225:112.5:135 kg $\mathrm{N}: \mathrm{P}_{2} \mathrm{O}_{5}: \mathrm{K}_{2} \mathrm{O}$ per ha in cv. Cudappah $\left(\mathrm{I}_{1} \mathrm{~V}_{1} \mathrm{~F}_{2}\right)$ and drip irrigation at 50 per cent soil moisture depletion with application of $225: 112.5: 135 \mathrm{~kg} \mathrm{~N}: \mathrm{P}_{2} \mathrm{O}_{5}: \mathrm{K}_{2} \mathrm{O}$ per ha in cv. Cudappah $\left(\mathrm{I}_{1} \mathrm{~V}_{2} \mathrm{~F}_{3}\right)$. Furrow irrigation at 50 per cent soil moisture depletion with application of $\mathrm{N}: \mathrm{P}_{2} \mathrm{O}_{5}: \mathrm{K}_{2} \mathrm{O}$ per ha in $\mathrm{Cv}$. Pratibha $\left(\mathrm{I}_{2} \mathrm{~V}_{2} \mathrm{~F}_{1}\right)$ which was on par $\mathrm{I}_{3} \mathrm{~V}_{2} \mathrm{~F}_{1}$ (Table 4). Whereas, Sadarunnisa et al., (2010) and Patel et al., (2012) obtained higher yields in drip irrigation with higher fertilizer over furrow irrigation with different fertilizers. Aulakh and Malhi (2005) indicated positive interaction effect of nitrogen with other nutrients in presence of water. Thus synergistic effect of higher levels of applied nutrients and drip irrigation method on $\mathrm{Cv}$. Cudappah combination might have proved to be positive in imparting the progressive growth and yield of turmeric.

Application of $\mathrm{N}: \mathrm{P}_{2} \mathrm{O}_{5}: \mathrm{K}_{2} \mathrm{O}$ fertilizer levels upto 225:112.5:135 kg N: $\mathrm{P}_{2} \mathrm{O}_{5}: \mathrm{K}_{2} \mathrm{O}$ per ha coupled with split application of $\mathrm{N}$ and $\mathrm{K}_{2} \mathrm{O}$ in balanced proportion with higher potassium ratio and drip method of irrigation resulted in higher fresh rhizome yield, fresh mother rhizome yield and cured finger rhizome yield in both the varieties tested.

\section{Acknowledgement}

Research work was conducted as part of $\mathrm{Ph}$. $D$ thesis at University of Agricultural Sciences, Dharwad under ICAR- Senior Research Fellowship. 


\section{References}

Anonymous, 2017, Spices wise area and production. Spices board of India, Ministry of commerce and industry, Government of India, Cochin. Retrieved from http://www.indianspices.com/ on 27-05-17.

Ati, A. S., Iyada, A. D. and Najim, S. M., 2012, Water use efficiency of potato (Solanum tuberosum L.) under different irrigation methods and potassium fertilizer rates. Ann. Agric. Sci., 57 (2): 219-223.

Aulakh, M. S. and Malhi, S. S., 2005, Interactions of nitrogen with other nutrients and water: Effect in crop yield and quality, nutrient use efficiency, carbon sequestration and environmental pollution. Adv. Agron., 86: 341409.

Chitra, R., Havaraddi, R. M., Subramanian, S. and Suresh, J., 2017, Effect of schedulling of drip irrigation on growth, yield and water use efficiency of turmeric (Curcuma longa L.) var. CO 2. J. Spices Aromatic Crops, 26 (1): 8-15.

Gomez, K. A. and Gomez, A. A., 1984, Statistical Procedures for Agricultural Research, An International Rice Research Institute Book, Willey Inter Science Publication, New York, USA, p.680.

Jagadeeswaran, R., Murugappan, V. and Govindaswamy, M., 2005, Study on the slow release NPK fertilizers on the dry matter production and rhizome yield of turmeric (Curcuma longa L.). Madras Agric. J., 92 (1012): 653-659.

Kaur, A. and Brar, A. S., 2016, Influence of mulching and irrigation scheduling on productivity and water use of turmeric (Curcuma longa L.) in north western India. Irrigation Sci., 34 (4): 261-269.

Patel, D. K., Patel, B. M., Patel, P. T., Patel, D. M., Patel, B. J., 2012, Influence of irrigation methods along with nitrogen and potash management on yield and nutrient uptake by potato. Agric. Sci. Dig., 32 (1): 38-42.
Sadarunnisa, S., Madhumathi, C., Rao, G. S. and Sreenivasulu, B., 2010, Effect of fertigation on growth and yield of turmeric cv. Mydukur. $J$. Horti. Sci., 5 (1): 78-80.

Salimath, S., Venkatesha, J. and Kotikal, Y, K., 2013, Evaluation of yield and quality of turmeric cultivars under southern dry zone of Karnataka In: Symposium on Spices, Medicinal and Aromatic Crops SYMSAC-VII 'PostHarvest Processing of Spices and Fruit Crops' $27^{\text {th }}-29^{\text {th }} \quad$ November 2013 , Madikeri, Karnataka, p. 209.

Salisbury, E. B. and Ross, C., 1969, Plant Physiology, The Wadsworth Botany Series, Prentice Hall of India Pvt. Ltd. Publishers. New Delhi, p. 748.

Sandeep, I. S., Kuanar, A., Akbar, A., Kar, B., Das, S., Mishra, A., Sial, P., Naik, P. K., Nayak, S. and Mohanty, S., 2016, Agroclimatic zone based metabolic profiling of turmeric (Curcuma longa L.) for phytochemical yield optimization. Industrial Crops Prod, 85: 229-240.

Seyie, A., Naruka, I. S., Singh, P. P. and Kushwah, S. S., 2013, Nutrient management and its effect on growth, yield and quality of ginger cultivars. Indian J. Hort., 70 (1): 65-70.

Siddramappa, S., 2013, Development schemes of spices. In: Symp. on Spices, Medicinal and Aromatic Crops SYMSAC-VII ' Post Harvest Processing of Spices and Fruit Crops, $27^{\text {th }}$ $29^{\text {th }}$ November, 2013, Madikeri, Karnataka, pp. 162-172.

Surepeddi, S., Kalidasu, G. and Naidu, N. L., 2016, Standardization of water requirement through drip irrigation in turmeric (Curcuma longa) for the Vertisols of Andhra Pradesh. Prog. Res., 11 (special-VII): 4757-4760.

Tiwari, S. K., Tiwari, J. K. and Pathak, M. K., 2014, Growth, yield and quality of turmeric (Curcuma longa L.) as influenced by planting time and fertilizer levels. J. Spices Aromatic Crops, 23 (1): 64-70.

\section{How to cite this article:}

Sunil A. Satyareddi and Angadi, S.S. 2017. Influence of Deficit Irrigation Using Different Irrigation Methods and Fertilizer Levels on Performance of Turmeric. Int.J.Curr.Microbiol.App.Sci. 6(11): 1419-1427. doi: https://doi.org/10.20546/ijcmas.2017.611.169 